\section{Az elmúlt tíz év változásainak vezetői értékelése különböző szervezeti formában müködő vállalatoknál}

\author{
Kerékjártó Gábor \\ Debreceni Egyetem Agrártudományi Centrum, \\ Agrárgazdasági és Vidékfejlesztési Intézet, \\ Vezetéstudományi Tanszék, Debrecen
}

\section{ÖSSZEFOGLALÁS}

Az elmúlt évtized olyan változásokat hozott a gazdasági élet valamennyi területén, melyek hatása ma még nehezen felmérhetö és meröben új követelményeket támaszt a vezetökkel szemben. A korábbi csendes stagnálást felváltotta az elöre nem tervezhetö dinamikus változékonyság, a bizonytalan gazdasági és társadalmi környezet. Tanulmányomban azt vizsgáltam, milyen nyomokat hagytak mindezen változások a vezetőkben, mely változásokat tartották/tartják fontosnak, mi befolyásolta legjelentösebben a szervezet müködését. Ennek alátámasztására kérdöives adatfelvételezést végeztem különbözö formában müködö, elsősorban mezögazdasági alapanyag-termeléssel és -feldolgozással foglalkozó vállalatok körében. Az eredmények azt mutatják, hogy három kiemelt területet tartanak fontosnak a vezetök. Ezek a következök:

- piaci változások,

- minőségi elvárások fokozódása,

- szervezeti átalakulás.

E három tényezö valamennyi szervezeti forma mindhárom vezetöi szintjén magas pontszámot kapott, azonban a többi tényezö tekintetében tapasztalhatók eltérések. Az alsóbb szintü vezetök leginkább a mindennapi munkát közvetlenül érintő kérdéseket, míg a felsővezetök elsösorban a vállalat érdekeit és jövőjét hosszú távon befolyásoló tényezőknek tulajdonitanak nagyobb jelentöséget.

\section{SUMMARY}

Last decade of Hungarian agriculture was featured by revolutions and changes. Effects of these changes can be sensible at all parts of agricultural production. It results in new ownership and organisation structure. Agriculture has to suit to the new circumstances of changed firm-size and structure. These kinds of changes essentially define conditions of agricultural production in the future, and they have an affect on husbandry of enterprises.

To be succeed in managing changes, we have to know the reasons of these alterations and nature of them. It is very important to get to know the advantages and disadvantages of the typical change-management methods and its typology. These methods are more elaborated and widespread at industrial enterprises. It is necessary to get to know the nature, characteristics and reasons of changes, and we should work out ways agricultural companies, taking notice of their speciality.

\section{The methods and means of examinations}

We aimed to point out what kind of changing processions were typified the activity of agricultural ventures. What are the speciality, strains, the arousing and obstructive factors of nowadays changes. We made questionnaire and sent them to numerous enterprises.

Most of the answers show that leaders are ,floating with flow" and most part of their power is used to fight back actually challenges. Generally consciousness is missing, so they are not govern the events still more they are passive objects of occurrence.

Naturally, the given answers show, that the most important changes of past are changing of markets, importance of quality production and changes in the structure of enterprises. And especially at companies, which deal with plant growing -, modifying of structure because of compensation.

A rendszerváltást követően az üzleti szervezetek vezetőinek merőben megváltozott gazdasági és politikai körülmények között kellett irányítaniuk a vállalatokat. Olyan átfogó és széleskörü változások történtek, melyek alapjaiban kell, hogy módosítsák a vezetés korábbi módszereit. Az állam, mint biztos háttér, a gazdasági élet legtöbb területén kivonult a felelősségvállalásból, s a szervezetek számára a hatékony módon, alacsony költséggel megvalósított minőségi termelés vált a piacon maradás egyetlen lehetséges eszközévé. Mint arra a hazai és nemzetközi menedzsment szakirodalom (Kotter, 1999) is felhívja a figyelmet, a ma vállalatának a korábbi stabilitással szemben a dinamikusan változó körülmények feltételrendszerét kell statikusnak elfogadni.

A korábban oly biztosnak tünő, és nem egyszer bizony az alacsonyabb minőséget is azonos áron, nagy tételben megvásárolni hajlandó orosz piac összeomlása, a küszöbön álló EU csatlakozás, a minőségbiztosítási rendszerek tömeges elterjedése mind olyan tényezők, melyek a vezetés szemléletének megújulását követelik. A vállalati menedzsment funkcionális vizsgálatával foglalkozó cikkében Berde is hangsúlyozza: „A vezetési feladatok megítélése állandóan változik...Különösen érvényes ez a mezögazdaság és az élelmiszeripar területén, ahol az elmúlt évtized gazdasági változásainak következményei nagymértékben befolyásolták a vezetés müködésének feltételeit, a vezetési struktúrákat, a vezetési feladatok rangsorát, fontosságát.”(Berde, 2001). Speciális területe miatt e változások hatványozottan éreztetik hatásukat a mezőgazdaságban és élelmiszeriparban. A termelés jellegére alapvetően rányomja bélyegét a természeti folyamatoknak való kitettség és az, hogy a termék elöállítás során élő szervezetekről van szó, így a biológiai határidők nagy jelentőséggel bírnak. Emellett természetesen a humán tényezők szerepe is felértékelődik (Dienesné, 1998).

Mint $\mathrm{PhD}$ hallgató a változás menedzsment mezőgazdasági vállalatokat és élelmiszeripari cégeket érintő kérdéseivel foglalkozom. Kérdőíves formában azt vizsgáltam, milyen kép él a vállalati vezetőkben a szervezetet érintő külső-belső 
változásokkal kapcsolatosan, és azokat egymással összehasonlítva milyen sorrendet tulajdonítanak a vezetők az egyes tényezőknek személyes tapasztalataik és szubjektív értékítéletük alapján. Megfigyelhető, hogy a vezetési hierarchia eltérő szintjein tevékenykedő válaszadók ugyanazon tényezőket más és más módon értékelték. Természetesen ebben nagy szerepet játszik a megkérdezettek életkora valamint az érintett szervezet termelési profilja is. Hasonló szempontok alapján végzett felmérést Juhász (1999) is, mikor 450 kérdőív adataira támaszkodva részletesen elemezte a különböző motivációs eszközök alkalmazásának lehetőségeit hazai mezőgazdasági vállalatoknál. Megállapításaiban kiemeli, hogy ellentmondások figyelhetők meg a vállalati vezetők és beosztottak megítélésében.

\section{A VIZSGALAT ADATBÁZISA}

$\mathrm{Az}$ általam vizsgált terület eredményinek elemzéséhez mintegy $401 \mathrm{db}$ interjú adatait vettem alapul. Ezen interjúk kérdőíves formában számos, egymással szorosan összefüggő vezetési kérdés véleményezését kívánják a válaszadótól. Jelen tanulmányban a kérdőívből kiemelten csupán egyetlen kérdés eredményeit elemzem. E kérdésnél a válaszadó feladata, hogy 1-től 10-ig terjedő pontszámmal értékelje a felsorolt tényezők fontosságát személyes értékítélete alapján. Társadalomtudományi felmérésről lévén szó célszerünek tartom elöre leszögezni azt, hogy a válaszadók által 1-től 10-ig terjedő skálán adott pontszámok csupán szubjektív értékítéletet tükröznek.

A következőkben röviden ismertetem a felmérés alapjául szolgáló vállalatok és személyek szerkezeti összetételét.

Összesen 401 db kérdöív adatai kerülnek értékelésre, melyek 121 db különböző vállalat eltérő vezetői szintjén tevékenykedő válaszadók véleményét tükrözik. Átlagosan tehát körülbelül $3 \mathrm{db}$ kérdőív származik azonos vállalattól. Szerencsés esetben ez azt jelenti, hogy az adott szervezetnél megkérdezett válaszadók között egy alsó, egy közép és egy felső szintü vezető található. Ez a tendencia általánosítható, azonban néhány esetben ettől eltérő összetétellel is találkozhatunk (pl. két felső- és csak egy középvezető).

A vizsgált szervezetek működési profil szerinti megoszlása az 1. ábra szerint alakult.

Látható tehát, hogy a megkérdezett szervezetek több mint 3/4-ed része a mezőgazdasággal szorosan összefüggő területen tevékenykedik, ezért úgy gondolom, a kapott eredmények jó közelítéssel általánosíthatók mezőgazdaság vállalatokra. Jelentősnek mondható továbbá az élelmiszeripari cégek aránya, melyek $10 \%$ körüli értékkel képviseltetik magukat. Vagyis a felmérés elsősorban az alapanyag-termelő és a velük feldolgozási kapcsolatban álló vállalatok vezetőinek véleményét tükrözi.
1. ábra: A megkérdezett szervezetek ágazatok szerinti tagozódása

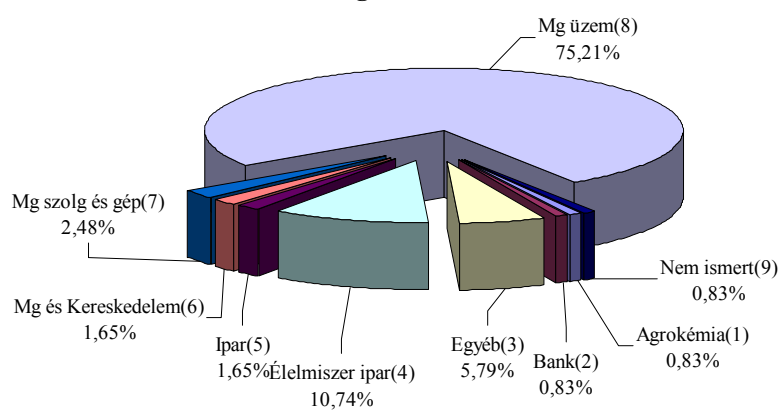

Figure 1: Composition of Examined Enterprises by The Sphere of Activities

agro-chemistry(1), $\operatorname{bank}(2), \quad$ others(3), food-industry(4), industry(5), agriculture and commercialism(6), agriculture and service(7), agricultural production(8), unknown(9)

Érdekes képet mutat a szervezetek müködési forma szerinti megoszlása is (2. ábra).

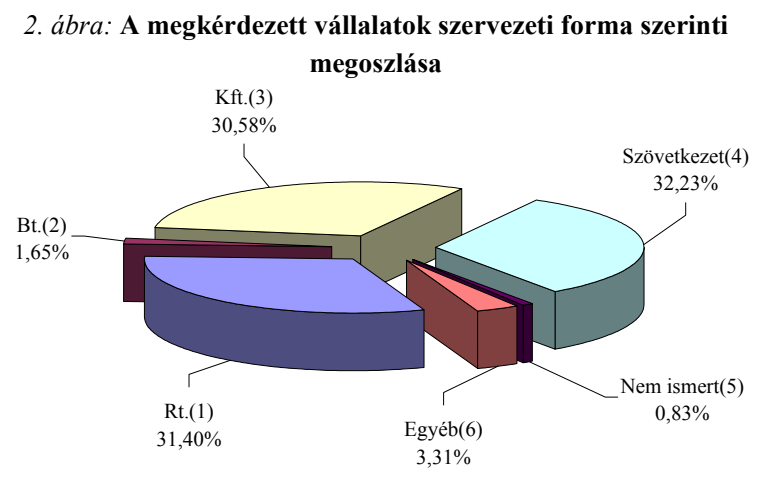

Figure 2: Composition of examined enterprises by organizational structure

public company(1), company(2), Limited company(3), cooperative(4), unknown(5), others(6)

Tehát a válaszadó vállalatok közel 30-30-30\%-os megoszlásban szövetkezeti formában, korlátolt felelösségü társaságként, illetve részvénytársasági formában tevékenykednek. Ez sajátos összehasonlításokra ad alkalmat, ugyanis a szövetkezeti forma minden bizonnyal magán hordozza még egykori mezőgazdasági termelőszövetkezeti jellegét, mivel csak az átalakulási törvény írta elő kötelező jelleggel e vállalatok számára az új típusú szövetkezetté történő átalakulást. A jelenlegi vezetés legnagyobb része a korábbi vezetők személyei közül kerül ki, így saját bőrükön tapasztalták a változások hatását, és személyesen tapasztalhatták az eltérő változáskezelési módszerek hatékonyságát. Más és más vezetési struktúrát feltételez a szinte családias légkörben müködő szövetkezeti modell, a legtöbb esetben a top menedzser személyes tulajdonában lévő $\mathrm{kft}$. forma, valamint a részvényesek érdekeit is szem elött tartani kénytelen és bizonyos mértékben a részvényesek által is ,irányított” részvénytársasági formában működő szervezet. 
A továbbiakban az egyes eltérö szervezeti formában üzemelő vállalatok alsó, közép és felső szintü vezetői által adott válaszokat értékelem. A jobb összehasonlíthatóság érdekében úgy gondolom, nem haszontalan röviden bemutatni a valamennyi feldolgozott kérdőív adatait beosztásra és működési profilra való tekintet nélkül bemutató diagram rangsorát (3. ábra).

\section{3. ábra: Minden megkérdezett értékítélete csökkenő} sorrendben

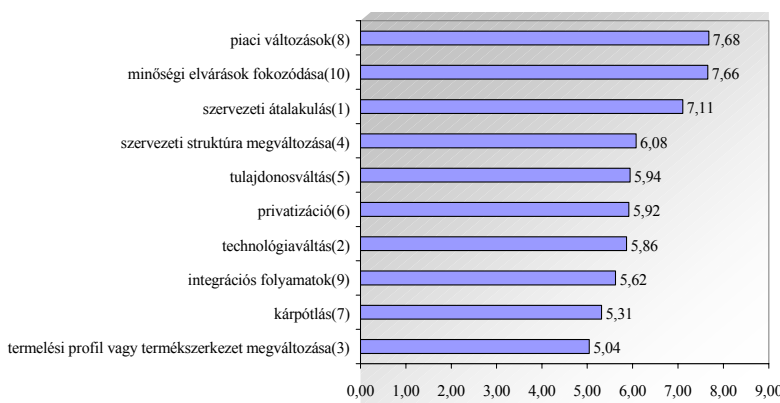

Figure 3: Value judgment of all of the answerers in decreasing sequence

organizational changing(1), changing of technology(2), changing of production profile(3), changing of organizational structure(4), changing of the owner(5), privatisation(6), compensation(7), changes of markets(8), integration processes(9), increasing of quality expections(10)

Habár a válaszadók értékítéletében tapasztalható differenciáltság elég szük intervallumban mozog (a legjelentősebbnek ítélt és legkevésbé fontosnak tartott változási tényező átlagos „fontosságpontszáma" között mindössze 2,64 a különbség!), azért jól elkülöníthető a három leghangsúlyosabb terület:

- piaci változások,

- minöségi elvárások fokozódása,

- szervezeti átalakulás.

Ez teljes összhangban van a bevezetésben hipotetikusan megemlített változásokkal. Ezek szerint a vizsgálat alanyául választott szervezetek vezetői - akik döntő többségükben mezőgazdasággal kapcsolatos területen tevékenykednek - kiemelt jelentőséget tulajdonítanak a piac által diktált minőségi elvárásoknak, saját börükön érzik a piaci viszonyok átstrukturálódását és a privatizációból fakadó szervezeti átalakulások hatását is.

Az való kölcsönös összehasonlíthatóság miatt az azonos szervezeti formában müködő vállalatok három vezetői szintjének rangsora közös, összevont ábrán kerül bemutatásra (4. ábra).

A szövetkezeteket vizsgálva a kapott eredmények szerint a szervezetei átalakulás közel azonos mértékben érintette valamennyi vezetői szintet. Amíg azonban a felsorolt tíz tényező közül valamennyi vezető szerint az egyik legkevésbé jelentős befolyásoló a közelgő EU csatlakozást is felölelö integrációs folyamat, addig a legfontosabbnak ítélt tényezők között jelentős eltérések mutatkoznak az egyes vezetői szinteken. Véleményem szerint az integrációs tevékenység iránt mutatkozó lanyha érdeklődés oka nem a vezetők helytelenül körvonalazott jövőképében keresendő, sokkal inkább annak tudható be, hogy a hirtelen megváltozott körülményeknek való pillanatnyi megfelelés felemészti az ehhez szükséges energiát. Kiemelt pontszámot kapott a fentebb már említett összátlaghoz hasonlóan itt is a piaci helyzet átalakulása, és a minőség ügye is, de meglepő módon a megkérdezettek közül a minőség az alsó szintü vezetők preferenciaskáláján kapta a legmagasabb értéket. A stratégiai döntéseket hozó, s ezáltal a vállalat tevékenységének is irányt adó felső vezetés nagyra értékelte a privatizáció és kárpótlás fontosságát is, ami érthető, hiszen mezőgazdasági tevékenység esetén meghatározó tényező a megfelelő mennyiségü saját földterület. A privatizáció az alsóés középvezetői szintek mindennapi munkáját nem befolyásolja, döntő mértékben, míg a megfelelő tőkeerővel rendelkező felső vezetés számára a hosszú távú eredményes befektetés fontos eszköze lehet. Úgy gondolom, hogy az alsó szintü vezetők által a tulajdonosváltás értékelésére adott alacsony pontszámok hátterében az a tény áll, hogy a tulajdonos és a hierarchia-piramis lábánál elhelyezkedő alsó szintü vezetők közvetlen, személyes kapcsolata ritka, s szerencsés esetben az új tulajdonos nem érdekelt abban, hogy a helyi viszonyokat legjobban ismerő, valamint az embereit megfelelően kezelni és motiválni képes alsóvezetői gárdát lecserélje.

\section{4. ábra: Eltérő vezetői szintek értékítélete szövetkezet típusú szervezeteknél}

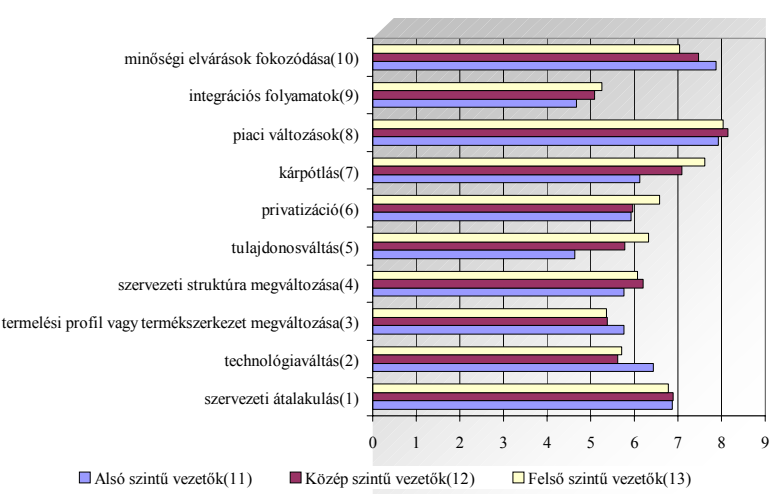

Figure 4: Different value judgments of different leaders at cooperatives

organizational changing(1), changing of technology(2), changing of production profile(3), changing of organizational structure(4), changing of the owner(5), privatisation(6), compensation(7), changes of markets(8), integration processes(9), increasing of quality expections(10), lower leaders(11), middle leaders(12), top leaders(13)

A részvénytársaságok vezetőinek értékrendje nagy hasonlóságot mutat az előbb ismertetett diagrammal (5. ábra). 


\section{5. ábra: Különböző vezetői szintek véleménye} Részvénytársaságoknál

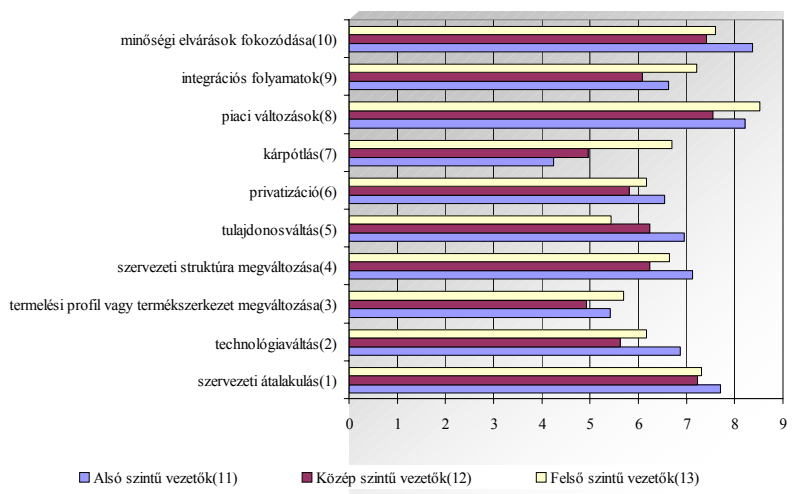

Figure 5: Different value judgments of different leaders at public companies

organizational changing(1), changing of technology(2), changing of production profile(3), changing of organizational structure(4), changing of the owner(5), privatisation(6), compensation(7), changes of markets(8), integration processes(9), increasing of quality expections(10), lower leaders(11), middle leaders(12), top leaders(13)

Említésre alkalmas különbségek csupán néhány helyen figyelhetők meg. Például a kárpótlás hatásainak vezetői megítélésekor felső vezetés kiugróan jelentősnek tartja azt a közép- és alsóvezetői szint átlagához képest. Továbbá a három vezetői szint értéksorának egymással való összehasonlításakor kitünik, hogy a részvénytársaságok esetében az alsóvezetést sokkal inkább megviselte a tulajdonos személyének6személyeinek megváltozása, mint a szövetkezeti modell esetében.

Általánosan megfigyelhető a diagramokon az is, hogy a topmenedzsment stratégiai céljait az alsó szintủ vezetés felé közvetítő középvezetői réteg véleménye tendenciáit tekintve leginkább a felső vezetéssel harmonizál, s attól csupán kis mértékben tér el. Érdekes megfigyelni azt is, mennyivel lényegesebbnek ítélik a részvénytársasági formában tevékenykedő, s a részvényesek nagy száma miatt több személy egyidejű érdekeit szem előtt tartó vállalatok vezetői az integrációs folyamatokat, mint a szövetkezetekben dolgozó kollégáik. Ennek oka talán abban kereshetö, hogy az egykori termelöszövetkezetek többsége korábban a biztos értékesítést garantáló állami piacokra termelt, $\mathrm{s}$ ez a gyakorlat nem követelte meg a vezetés részéröl, hogy figyelemmel kísérje a termékpálya teljes vertikumát, esetleges külföldi kapcsolatrendszereket.

A korlátolt felelősségü társaságok irányítása sokszor egy személy kezében összpontosul, aki ügyvezető igazgatóként látja el vezetői feladatait. Éppen ezért a felelősségi körök erős koncentrálódása figyelhető meg, és sok esetben a szervezeti hierarchia felépítése is lényegesen egyszerübb képet mutat például a részvénytársaságokéval összehasonlítva ( 6 . ábra).

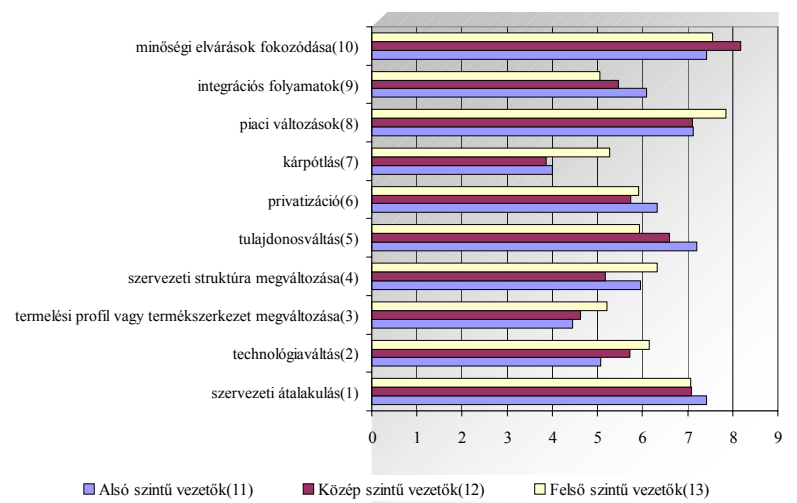

Figure 6: Different value judgments of different leaders at limited companies

organizational changing(1), changing of technology(2), changing of production profile(3), changing of organizational structure(4), changing of the owner(5), privatisation(6), compensation(7), changes of markets(8), integration processes(9), increasing of quality expections(10), lower leaders(11), middle leaders(12), top leaders(13)

Éppen a fent említett okok miatt érthető, hogy az Rt. és szövetkezeti vezetők rangsorával ellentétesen, a Kft-k esetében a tulajdonosváltást a felsővezetők tartották a legjelentősebb változások egyikének, hiszen esetükben itt személyes ügyről volt szó.

A továbbiakban röviden szeretném bemutatni, hogyan alakult az egyes vezetői szintek fontosságrangsora külön-külön az eltérö szervezeti formák esetén (1. táblázat). Fontos megemlíteni, hogy itt nem az egyes válaszadók által adott pontszámok szerepelnek, hanem az azok átlagából a vizsgált tényezők fontosságára vonatkozó rangsort jeleníti meg. Vagyis az 1-es számjegy azt jelenti, hogy a megkérdezett tíz tényező közül a válaszadó ezt tartotta a legjelentősebb változásnak, míg 10-es érték esetén a számára legkevésbé jelentős válaszról van szó.

Mind az Rt., mind pedig a Kft. szervezetek alsóvezetői szerint a legjelentősebb kihívás a minőség területén jelentkezik, ugyanakkor a szövetkezetek a piacok átalakulását teszik első helyre. Szignifikáns eltérés mutatkozik a kárpótlás területén. A szövetkezeti vezetők a tíz tényezö közül az 5. helyre rangsorolták, ami összehasonlítva a másik két csoport 10., utolsó helyével relatíve nagy fontosságot feltételez. E kijelentés teljes összhangban áll azzal a feltételezéssel, hogy a szövetkezeti formában működő vállalatok nagy többsége a földterülethez szorosan kötődő alapanyag-termelö tevékenységet folytat (2. táblázat).

A középszintủ vezetők a piaci változások jelentősségét hangsúlyozták, ugyanakkor a „termelési profil vagy termékszerkezet megváltozása" tényezőnek szentelték a legkevesebb figyelmet. Látszik az is, mennyivel közelebbről érintette az Rt. és Kft. vezetőket a tulajdonosváltás, mint szövetkezeti társaikat (3. táblázat). 
1. táblázat

Alsó szintü vezetők rangsora működési formák szerint

\begin{tabular}{|l|r|r|r|}
\hline \multirow{2}{*}{ Alsó szintű vezetők(11) } & \multicolumn{3}{|c|}{ Múködési forma(12) } \\
\cline { 2 - 4 } & $\begin{array}{c}\text { Szöv. } \\
\text { (13) }\end{array}$ & $\begin{array}{c}\text { Rt. } \\
\text { (14) }\end{array}$ & $\begin{array}{c}\text { Kft. } \\
\text { (15) }\end{array}$ \\
\hline szervezeti átalakulás(1) & 3 & 3 & 2 \\
\hline technológiaváltás(2) & 4 & 6 & 8 \\
\hline termelési profil vagy termékszerkezet & & & \\
megváltozása(3) & 8 & 9 & 9 \\
\hline szervezeti struktúra megváltozása(4) & 7 & 4 & 7 \\
\hline tulajdonosváltás(5) & 10 & 5 & 3 \\
\hline privatizáció(6) & 6 & 8 & 5 \\
\hline kárpótlás(7) & 5 & 10 & 10 \\
\hline piaci változások(8) & 1 & 2 & 4 \\
\hline integrációs folyamatok(9) & 9 & 7 & 6 \\
\hline minőségi elvárások fokozódása(10) & 2 & 1 & 1 \\
\hline
\end{tabular}

Table 1: Gradiation of lower leaders at different kind of organizations

organizational changing(1), changing of technology(2), changing of production profile(3), changing of organizational structure(4), changing of the owner(5), privatization(6), compensation(7), changes of markets(8), integration processes(9), increasing of quality expections(10), lower leaders(11), organizations(12), Cooperative(13), Public Company(14), Limited Company(15)

\section{2. táblázat}

Közép szintű vezetők rangsora múködési formák szerint

\begin{tabular}{|l|r|r|r|}
\hline \multirow{2}{*}{\multicolumn{1}{|c|}{ Közép szintű vezetők(11) }} & \multicolumn{3}{|c|}{ Müködési forma(12) } \\
\cline { 2 - 4 } & $\begin{array}{c}\text { Szöv. } \\
\text { (13) }\end{array}$ & $\begin{array}{c}\text { Rt. } \\
(\mathbf{1 4})\end{array}$ & $\begin{array}{c}\text { Kft. } \\
(\mathbf{1 5})\end{array}$ \\
\hline szervezeti átalakulás(1) & 4 & 3 & 3 \\
\hline technológiaváltás(2) & 8 & 8 & 6 \\
\hline termelési profil vagy termékszerkezet & & & \\
megváltozása(3) & 9 & 10 & 9 \\
\hline szervezeti struktúra megváltozása(4) & 5 & 5 & 8 \\
\hline tulajdonosváltás(5) & 7 & 4 & 4 \\
\hline privatizáció(6) & 6 & 7 & 5 \\
\hline kárpótlás(7) & 3 & 9 & 10 \\
\hline piaci változások(8) & 1 & 1 & 2 \\
\hline integrációs folyamatok(9) & 10 & 6 & 7 \\
\hline minőségi elvárások fokozódása(10) & 2 & 2 & 1 \\
\hline
\end{tabular}

Table 2: Gradiation of middle leaders at different kind of organizations

organizational changing(1), changing of technology(2), changing of production profile(3), changing of organizational structure(4), changing of the owner(5), privatization(6), compensation(7), changes of markets(8), integration processes(9), increasing of quality expections(10), lower leaders(11), organizations(12), Cooperative(13), Public Company(14), Limited Company(15)
Felső szintű vezetők rangsora müködési formák szerint

\begin{tabular}{|l|r|r|r|}
\hline \multirow{2}{*}{ Felső szintű vezetők(11) } & \multicolumn{3}{|c|}{ Müködési forma(12) } \\
\cline { 2 - 4 } & $\begin{array}{c}\text { Szöv. } \\
\text { (13) }\end{array}$ & $\begin{array}{c}\text { Rt. } \\
\text { (14) }\end{array}$ & $\begin{array}{c}\text { Kft. } \\
\text { (15) }\end{array}$ \\
\hline szervezeti átalakulás(1) & 4 & 3 & 3 \\
\hline technológiaváltás(2) & 8 & 8 & 5 \\
\hline termelési profil vagy termékszerkezet & & & \\
megváltozása(3) & 9 & 9 & 9 \\
\hline szervezeti struktúra megváltozása(4) & 7 & 6 & 4 \\
\hline tulajdonosváltás(5) & 6 & 10 & 6 \\
\hline privatizáció(6) & 5 & 7 & 7 \\
\hline kárpótlás(7) & 2 & 5 & 8 \\
\hline piaci változások(8) & 1 & 1 & 1 \\
\hline integrációs folyamatok(9) & 10 & 4 & 10 \\
\hline minőségi elvárások fokozódása(10) & 3 & 2 & 2 \\
\hline
\end{tabular}

Table 3: Gradiation of top leaders at different kind of organizations

organizational changing(1), changing of technology(2), changing of production profile(3), changing of organizational structure(4), changing of the owner(5), privatization(6), compensation(7), changes of markets(8), integration processes(9), increasing of quality expections(10), lower leaders(11), organizations(12), Cooperative(13), Public Company(14), Limited Company(15)

A stratégiai célokat megfogalmazó, és a vállalat hajójának irányításáért felelös felső vezetés szintjén egyértelmüen a megváltozott piaci körülmények közötti talponmaradás és az ehhez elengedhetetlenül szükséges minőségi termelés megvalósítása a két legkiemeltebb tényező.

\section{IRODALOM}

Berde Cs. (2001): A vezetési feladatok változása a mezőgazdasági innováció folyamatában. Innováció, a tudomány és a gyakorlat egysége az ezredforduló agráriumában c. tudományos rendezvény kiadványa, Gödöllő

Dienesné K. E. (1998): Humánmenedzsment kérdések a mezőgazdasági minőségbiztosításban. XXVII. Óvári Tudományos Napok, Mosonmagyaróvár

Juhász Cs. (1999): Vezetői, dolgozói motiváltság összehasonlító vizsgálata a mezőgazdaságban. II. Alföldi Tudományos Tájgazdálkodási Napok, Mezőtúr

Kotter P. (1999): A változások irányítása. Kossuth Kiadó, Budapest 